\title{
PENGARUH PENAMBAHAN LIMBAH GRANIT TERHADAP KUAT TEKAN BETON
}

\author{
SURYA HADI \\ Fakultas Teknik Universitas Al - Azhar Mataram \\ e-mail : hdsurya11@gmail.com
}

\begin{abstract}
ABSTRAK
Beton merupakan suatu campuran yang terdiri dari campuran semen, pasir, kerikil, dan air. Untuk mendapatkan mutu yang baik dalam pengerjaannya ditambahkan bahan tambahan (admixture atau additive), limbah ataupun bahan lainnya dengan nilai perbandingan tertentu. Dalam hal ini, penggunaan limbah granit dan batu alam sebagai bahan pembuatan beton cukup potensial karena limbah granit dan batu alam sebagai bahan pembuatan beton mudah ditemukan. Pada penelitian ini dilakukan pengujian dengan metode destruktif. Penelitian ini bertujuan untuk mengetahui kuat tekan beton dengan memanfaatkan limbah granit dan batu alam sebagai bahan pembuatan beton. Pada penelitian ini digunakan 12 (dua belas) buah benda uji berbentuk silinder dengan ukuran diameter $150 \mathrm{~mm}$ dan tinggi $300 \mathrm{~mm}$, dengan persentase penambahan limbah granit sebesar $0 \%, 8 \%, 10 \%$ dan 12\%. Pengujian dilakukan setelah beton berumur 28 hari sesuai dengan ASTM C496-90, kemudian benda uji silinder diuji dengan beban tekan menggunakan alat CTM (Compression Testing Mechine). Kuat tekan yang direncanakan adalah sebesar $25 \mathrm{MPa}$. Dari hasil penelitian diperoleh kuat tekan beton normal sebesar 26.09 MPa. Pada penambahan limbah granit dengan persentase 8 $\%, 10 \%$ dan $12 \%$ diperoleh kuat tekan masing - masing sebesar 24.58 MPa, 22.69 MPa dan 21.28 MPa. Penambahan limbah granit pada beton normal ternyata mengurangi kuat tekan beton. Semakin tinggi persentase penambahan limbah granit, kuat tekan beton semakin menurun. Pada penelitian ini disimpulkan bahwa kuat tekan beton normal lebih tinggi dibandingkan dengan beton dengan penambahan limbah granit.
\end{abstract}

Kata kunci : Kerikil alam, kerikil pecah, kuat tekan, limbah granit.

\section{ABSTRACT}

Concrete is a mixture consisting of cement, sand, gravel, and water. To get good quality in the process it is necessary to add additional materials (admixture or additive), waste, or other materials with a certain comparison value. In this case, the use of granite and natural stone waste as a material for making concrete is quite potential because the waste of granite and natural stone as a material for making concrete is easy to find. In this study, a destructive method testing is used make concrete. This study aims to determine the compressive strength of concrete by utilizing waste granite and natural stone as a material for making concrete. In this study 12 (twelve) cylindrical specimens are used with a diameter of $150 \mathrm{~mm}$ and a height of $300 \mathrm{~mm}$, with a percentage increase in granite waste of $0 \%, 8 \%, 10 \%$ and $12 \%$. The test is carried out after 28 days of concrete in accordance with ASTM C496-90, then the cylindrical test specimens are tested with a compressive load using a CTM (Compression Testing Mechine). The planned compressive strength is 25 MPa. From the results of the study, the normal compressive strength of $26.09 \mathrm{MPa}$ is obtained. On the addition of granite waste with a percentage of $8 \%, 10 \%$ and $12 \%$, the compressive strength is obtained at 24.58 MPa, 22.69 MPa and 21.28 MPa respectively. Addition of granite waste to normal concrete actually reduces the compressive strength of concrete. The higher the percentage of additional granite waste, the weaker compressive strength of concrete becomes. In this study it is concluded that the compressive strength of normal concrete is higher than that of concrete with the addition of granite waste.

Keywords: Natural gravel, broken gravel, compressive strength, granite waste. 


\section{PENDAHULUAN}

\section{Latar Belakang}

Beton merupakan suatu campuran yang terdiri dari campuran semen, pasir, kerikil, dan air. Untuk mendapatkan mutu yang baik dalam pengerjaannya ditambahkan bahan tambahan (admixture atau additive), limbah ataupun bahan lainnya dengan nilai perbandingan tertentu. Selain itu, cara pencampuran maupun pengerjaannya juga mempengaruhi kekuatan, keawetan serta sifat beton tersebut. Pemakaian beton semakin besar penggunaannya, namun bahan penyusun yang digunakan semakin mahal dan terbatas. Para peneliti telah banyak melakukan inovasi-inovasi bahan pencampuran beton untuk diuji coba agar bahan penyusunnya menjadi lebih kuat dan ekonomis. Seiring dengan perkembangan teknologi material, khususnya teknologi beton, muncul gagasan untuk memanfaatkan limbah sebagai bahan penyusun maupun bahan tambah. Salah satunya dengan cara menambahkan limbah granit pada campuran beton.

Untuk mengetahui kualitas suatu beton perlu dilakukan pengujian terhadap beton tersebut. Pengujian dapat dilakukan dengan cara destruktif. Cara destruktif adalah pengujian yang sifatnya merusak benda uji, sempel ditekan sampai pecah, sehingga didapatkan data kuat tekan beton yang sifatnya aktual.

Pada penelitian ini, pengujian dengan cara destruktif digunakan untuk mengetahui kuat tekan pada beton yang dicampur dengan bahan tambah limbah granit dan agregat kasar yang digabungkan dengan agregat alam kemudian akan dibandingkan dengan beton normal.

\section{Rumusan Masalah}

Berdasarkan latar belakang diatas maka didapatkan beberapa permasalahan yaitu :

1. Bagaimanakah nilai perbandingan kuat tekan beton normal dengan beton campuran agregat kerikil pecah dan kerikil alam dengan penambahan limbah granit dengan persentase $0 \%, 8 \%, 10 \%$, dan $12 \%$ ?

2. Bagaimana pengaruh penambahan limbah granit pada campuran beton?

\section{Tujuan Penelitian}

Berdasarkan rumusan masalah diatas maka didapatkan tujuan yaitu:

1. Untuk mengetahui nilai perbandingan kuat tekan beton normal dengan beton campuran agregat kerikil pecah dan kerikil alam dengan penambahan limbah granit dengan persentase $0 \%, 8 \%, 10 \%$, dan $12 \%$.

2. Untuk mengetahui bagaimana pengaruh penambahan limbah granit pada campuran beton.

\section{METODE PENELITIAN}

\section{Lokasi Penelitian}

Penelitian ini dilaksanakan di Laboratorium Struktur dan Bahan Fakultas Teknik Universitas Islam Al Azhar Mataram dan Universitas Mataram. Dan lokasi pengambilan limbah granit diambil dari kota mataram

\section{Persiapan Penelitian}

Bahan yang digunakan dalam penelitian ini adalah sebagai berikut :

a. Air

Air yang digunakan adalah air bersih dari jaringan air yang ada di Laboratorium Struktur dan Bahan Fakultas Teknik Universitas Islam Al - Azhar Mataram. Pengujian terhadap air tidak dilakukan secara visual air tersebut cukup bersih untuk digunakann sebagai material penyusun beton.

b. Semen

Semen yang digunakan adalah semen Portland merk Tiga Roda dengan kemasan kantong $50 \mathrm{~kg}$. Semen yang digunakan dalam keadaan tertutup, kemasan tidak rusak, bahan butiran halus, tidak terjadi gumpalan yang dapat diamati secara visual.

c. Agregat Halus (Pasir)

Dalam penelitian ini pasir yang digunakan berasal dari Gunung sari, Kecamatan Gunungsari, Kabupaten Lombok Barat. Sebelum digunakan pasir terlebih dahulu dilakukan pencucian untuk menghilangkan kadar lumpur yang menempel di sekitar pasir. Pasir adalah butiran mineral alami yang berfungsi sebagai 
bahan pengisi dalam campuran mortar atau beton. Pasir yang digunakan tidak boleh mengandung lumpur lebih dari 5\% karena lumpur yang ada akan menghalangi ikatan antara pasir dan pasta semen.

d. Agregat Kasar (Kerikil)

Dalam penelitian ini kerikil yang digunakan berasal dari Gunung sari, Kecamatan Gunungsari, Kabupaten Lombok Barat. Sebelum digunakan kerikil terlebih dahulu dilakukan pencucian untuk menghilangkan kadar lumpur yang menempel di sekitar kerikil, kemudian kerikil tersebut dikeringkan untuk mendapatkan kerikil dengan kondisi jenuh kering muka.

\section{Pelaksanaan Penelitian}

\section{Persiapan}

Pada tahap persiapan ini meliputi kegiatan mengumpulkan alat dan bahan yang diperlukan, yaitu air, semen, pasir, kerikil pecah, kerikil alam, limbah granit. Air yang dipakai adalah air bersih dari PDAM.

\section{Pengujian Pasir}

Pengujian pasir meliputi :Pemeriksaan Berat Satuan Unit (unit weight), Pemeriksaan Gradasi Pasir (sieve analysis), Pemeriksaan Berat Jenis Pasir, Pemeriksaan Kadar Lumpur Pasir dan modulus kehalusan.

\section{Pengujian Kerikil}

Pengujian kerikil meliputi : Pemeriksaan Gradasi Kerikil, Pemeriksaan Berat Jenis Kerikil, modulus keahalusan.

\section{a. Pengujian Slump Beton}

Pengujian slump beton bertujuan untuk mengetahui kekentalan dari beton yang akan dibuat.

\section{b. Jumlah Benda Uji}

Adapun kebutuhan benda uji untuk pengujian kuat tekan adalah seperti ditunjukkan pada Tabel 3.1.

Tabe 1. Rencana Jumlah Benda Uji

\begin{tabular}{|c|c|c|c|c|}
\hline No & Kode Benda Uji & Persentase (\%) & $\begin{array}{c}\text { Umur Pengujian } \\
\text { (Hari) }\end{array}$ & $\begin{array}{c}\text { Jumlah Kebutuhan } \\
\text { Benda Uji }\end{array}$ \\
\hline 1 & BN & 0 & 28 & 6 \\
\hline 2 & BT I & 8 & 28 & 6 \\
\hline 3 & BT II & 10 & 28 & 6 \\
\hline 4 & BT III & 12 & 28 & 6 \\
\hline \multicolumn{2}{|c|}{ Total Jumlah Kebutuhan Benda Uji } \\
\hline
\end{tabular}

dengan :

$\mathrm{BN}=$ Beton Normal $0 \%$

BT I $=$ Beton dengan tambahan limbah granit $8 \%(8 \%$ dari agregat kasar $)$

BT II $=$ Beton dengan tambahan limbah granit $10 \%$ (10\% dari agregat kasar)

BT III $=$ Beton dengan tambahan limbah granit $12 \%$ (12\% dari agregat kasar)

Catatan : Agregat kasar $=50 \%$ kerikil pecah $+50 \%$ kerikil alam.

\section{d. Uji Kuat Tekan}

Pengujian kuat tekan beton dengan menggunakan alat Compression Testing Machine (CTM).

\section{HASIL DAN PEMBAHASAN}

\section{Hasil Pemeriksaan Bahan Penyusun Beton}

Hasil pemeriksaan bahan penyusun beton yang dilaksanakan di Laboratorium Struktur dan Bahan Fakultas Teknik Universitas Islam Al-Azhar Mataram diperoleh hasil seperti terlihat pada Tabel 2. 
Tabel 2. Hasil Pemeriksaan Bahan Penyusun Beton

\begin{tabular}{|c|l|c|c|c|c|}
\hline \multirow{2}{*}{ No } & \multicolumn{1}{|c|}{ Pemeriksaan Bahan } & \multicolumn{3}{|c|}{ Sampel (gram) } \\
\cline { 4 - 6 } & & \multirow{2}{*}{ Pasir } & \multicolumn{2}{|c|}{ Kerikil } & \multirow{2}{*}{$\begin{array}{c}\text { Limbah } \\
\text { Granit }\end{array}$} \\
\cline { 4 - 6 } & & & Pecah & Alam & \\
\hline \multirow{2}{*}{1} & Berat Satuan Agregat & & & & \\
\cline { 3 - 6 } & Berat Satuan Lepas & 1.46 & 1.53 & 1.57 & 1.50 \\
\cline { 3 - 6 } & Berat Satuan Padat & 1.52 & 1.55 & 1.60 & 1.53 \\
\hline \multirow{2}{*}{2} & Berat Jenis & & & & \\
\cline { 2 - 6 } & Berat Jenis Kering & 2.37 & 2.51 & 2.53 & 2.50 \\
\cline { 2 - 6 } & Berat Jenis SSD & 2.49 & 2.53 & 2.56 & 2.52 \\
\hline 3 & Kadar Lumpur & 1.71 & - & - & - \\
\hline 4 & Gradasi (MHB) & 2.47 & 6.53 & 6.55 & 6.50 \\
\hline
\end{tabular}

\section{Uji Kuat Tekan}

Pengujian kuat tekan dilakukan dengan menggunakan alat Compression Testing Machine (CTM) di Laboratorium Struktur dan Bahan Fakultas Teknik Universitas Mataram. Pengujian dilakukan setelah beton mengalami perawatan dan mencapai umur 28 hari. Hasil pengujian kuat tekan seperti Tabel 3 dan Grafik 1.

Tabel 3. Hasil Pengujian Kuat Tekan Beton

\begin{tabular}{|c|c|c|c|c|c|c|}
\hline \multirow{2}{*}{$\begin{array}{c}\text { Kode } \\
\text { Benda } \\
\text { Uji }\end{array}$} & \multirow{2}{*}{$\begin{array}{c}\text { No } \\
\text { Benda } \\
\text { Uji }\end{array}$} & \multirow{2}{*}{$\begin{array}{c}\begin{array}{c}\text { Kadar } \\
\text { Limbah } \\
\text { Granit }\end{array} \\
(\%)\end{array}$} & \multicolumn{2}{|c|}{ P Max } & \multirow{2}{*}{$\begin{array}{c}\begin{array}{c}\text { f'c } \\
\text { Pmax/A }\end{array} \\
\text { (Mpa) }\end{array}$} & \multirow{2}{*}{$\begin{array}{c}\text { f'c } \\
\text { Rata- } \\
\text { Rata } \\
\text { (Mpa) }\end{array}$} \\
\hline & & & $\mathbf{k N}$ & $\mathbf{N}$ & & \\
\hline \multirow{6}{*}{$\mathrm{BN}$} & 1 & \multirow{6}{*}{0} & 455 & 455000 & 25.76 & \multirow{6}{*}{26.09} \\
\hline & 2 & & 460 & 460000 & 26.04 & \\
\hline & 3 & & 450 & 450000 & 25.48 & \\
\hline & 4 & & 455 & 455000 & 25.76 & \\
\hline & 5 & & 485 & 485000 & 27.46 & \\
\hline & 6 & & 460 & 460000 & 26.04 & \\
\hline \multirow{6}{*}{ BT I } & 1 & \multirow{6}{*}{8} & 450 & 450000 & 25.48 & \multirow{6}{*}{24.58} \\
\hline & 2 & & 425 & 425000 & 24.06 & \\
\hline & 3 & & 440 & 440000 & 24.91 & \\
\hline & 4 & & 445 & 445000 & 25.19 & \\
\hline & 5 & & 410 & 410000 & 23.21 & \\
\hline & 6 & & 435 & 435000 & 24.63 & \\
\hline \multirow{6}{*}{ BT II } & 1 & \multirow{6}{*}{10} & 380 & 380000 & 21.51 & \multirow{6}{*}{22.69} \\
\hline & 2 & & 420 & 420000 & 23.78 & \\
\hline & 3 & & 380 & 380000 & 21.51 & \\
\hline & 4 & & 415 & 415000 & 23.50 & \\
\hline & 5 & & 385 & 385000 & 21.80 & \\
\hline & 6 & & 425 & 425000 & 24.06 & \\
\hline \multirow{6}{*}{ BT III } & 1 & \multirow{6}{*}{12} & 375 & 375000 & 21.23 & \multirow{6}{*}{21.28} \\
\hline & 2 & & 350 & 350000 & 19.82 & \\
\hline & 3 & & 390 & 390000 & 22.08 & \\
\hline & 4 & & 395 & 395000 & 22.36 & \\
\hline & 5 & & 350 & 350000 & 19.82 & \\
\hline & 6 & & 395 & 395000 & 22.36 & \\
\hline
\end{tabular}

Grafik 1. Hasil Pengujian Kuat Tekan

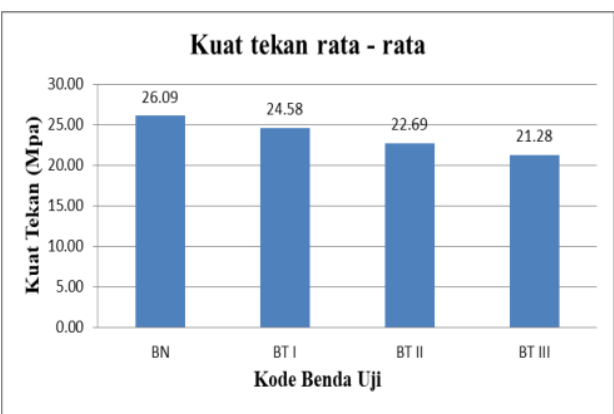


Pada Grafik 2 menunjukkan bahwa hasil kuat tekan maksimum yaitu pada beton normal sebesar 26.09 $\mathrm{MPa}$, sedangkan pada beton dengan penambahan limbah granit dengan persentase $8 \%$ adalah 24,58 , dengan penambahan $10 \%$ sebesar 22,69, dan dengan penambahan limbah granit $12 \%$ sebesar 21,28.

Dari hasil kuat tekan tersebut diketahui bahwa kuat tekan beton normal masih lebih besar dibandingkan dengan beton dengan penambahan limbah granit. Perbedaan kuat tekan antara beton normal dan beton dengan penambahan limbah granit tersebut menurun tidak terlalu besar, masih dapat diterima sebagai campuran beton karena masih berkisar pada pada distribusi normal dengan toleransi kuat tekan yang ditrima berkisar kurang lebih $5 \%$.

\section{SIMPULAN DAN SARAN}

\section{Simpulan}

Dari hasil penelitian dapat disimpulkan bahwa:

1. Kuat tekan beton normal (BN) sebesar 26.09 MPa. Pada penambahan limbah granit dengan persentase 8 \% (BT I) sebesar $24.58 \mathrm{MPa}$, penambahan $10 \%$ (BT II) adalah $22.69 \mathrm{MPa}$, dan pada penambhan $12 \%$ (BT III) sebesar $21.28 \mathrm{MPa}$.

2. Kuat tekan beton normal masih lebih tinggi dibandingkan dengan beton dengan penambahan limbah granit. Semakin tinggi persentase penambahan limbah granit yang digunakan, kuat tekan beton semakin menurun.

\section{Saran}

Berdasarkan penelitian yang telah dilakukan maka saran untuk penelitian selanjutnya adalah membandingkan kuat tekan beton normal dengan beton campuran agregat kerikil pecah (tidak ditambahkan dengan agregat alam) dengan penambahan limbah granit dengan persentase kisaran 3\% - $8 \%$.

\section{DAFTAR PUSTAKA}

Kardiyono Tjokrodimuljo, 2003, Teknologi Beton. Program Studi Teknik Sipil, Fakultas Teknik, Universitas Gadjah Mada. Yogyakarta.

Kardiyono Tjokrodimuljo, 2004, Teknologi Beton. Program Studi Teknik Sipil, Fakultas

Teknik,Universitas Gadjah Mada. Yogyakarta.

Neville dan Brooks,1987, Definisi Semen Portland.

SNI 03-2834-1992, Batas-Batas Gradasi Agregat Halus dan Batas-Batas Gradasi Agregat Kasar.

SNI 03-2834-1992, Persyaratan Kekerasan Agregat Kasar.

SNI 03.2847 pasal 7.3.1.2, Faktor Modifikasi Untuk Deviasi Standar Jika Tersedia Benda Uji Tes < 30.

SNI 03.2847 pasal 7.3.2.2, Kuat Tekan Rata-Rata Perlu Jika Data Tidak Tersedia Untuk Menetapkan Deviasi Standar.

SNI 15-2049-2004, Komposisi Semen dan Batasan.

Tjokrodimuljo, 1996, Definisi Beton, Definisi Air dan Agregat, Definisi Bahan Tambah, Penggolongan Bahan Tambah. Yogyakarta.

Tri Mulyono,. 2005, Teknologi Beton. Yogyakarta.

Wuryati Samekto,. dan Candra Rahmadiyanto, 2001, Teknologi Beton. Yogyakarta. 